\title{
Green manuring with Calotropis procera for the production of coriander in two growing seasons
}

\section{Adubação verde com Calotropis procera na produção de coentro em duas épocas de cultivo}

\author{
Ênio Gomes Flôr Souza ${ }^{\star}$, Almir Rogerio Evangelista de Souza², Enielson Bezerra Soares², \\ Aurélio Paes Barros Júnior², Lindomar Maria da Silveira², Francisco Bezerra Neto ${ }^{2}$
}

\author{
'Instituto Federal de Educação, Ciência e Tecnologia de Alagoas/IFAL, Piranhas, AL, Brasil \\ 2Universidade Federal Rural do Semi-Árido/UFERSA, Programa de Pós-Graduação em Fitotecnia, Mossoró, RN, Brasil \\ ${ }^{*}$ Corresponding author: eniosouzape@gmail.com \\ Received in May 5, 2017 and approved in July 25, 2017
}

\begin{abstract}
The use of spontaneous species of the Caatinga biome can contribute significantly to the nutritional demand of vegetable crops, thereby providing an agroecological and sustainable form of production. The objective of this research was to determine the effects of different biomasses of Calotropis procera (rooster tree) and times of incorporation into the soil of green manure during two growing seasons on the agronomic performance of coriander cv. Verdão produced in Serra Talhada, a semi-arid region of Pernambuco, Brazil. The experimental design was randomized blocks with three replications. The treatments were arranged in a $4 \times 4$ factorial scheme, with the first factor consisting of biomass amounts of $C$. procera $\left(5.4,8.8,12.2\right.$ and $15.6 \mathrm{t} \mathrm{ha}^{-1}$ on a dry basis) and the second by the incorporation times into the soil $(0,10,20$ and 30 days before coriander planting). The evaluated characteristics were plant height, number of stems per plant, yield of green mass and dry mass of shoot. The best productive performance of coriander was observed in amounts of 12.2 (spring) and 8.8 (autumn-winter) $\mathrm{t} \mathrm{ha}^{-1}$ C. procera added to the soil, with an ideal incorporation time of 13 (spring) and 23 (autumn-winter) days before sowing of the crop and with larger accumulations of green and dry mass of the shoot being obtained in autumn-winter.
\end{abstract}

Index terms: Coriandrum sativum L.; organic cultivation; rooster tree.

\begin{abstract}
RESUMO
O uso de espécies espontâneas do bioma Caatinga pode contribuir de forma significativa no suprimento nutricional demandado pelas hortaliças, sendo uma forma agroecológica e sustentável de produção. O objetivo da pesquisa foi determinar os efeitos de quantidades de biomassa de Calotropis procera (flor-de-seda), de tempos de incorporação ao solo do adubo verde e de duas épocas de cultivo sobre o desempenho agronômico do coentro cv. Verdão produzido em Serra Talhada, semiárido de Pernambuco, Brasil. O delineamento experimental foi em blocos casualizados, com três repetições. Os tratamentos foram arranjados em esquema fatorial $4 \times 4$, com o primeiro fator constituído por quantidades de biomassa de C. procera $(5,4 ; 8,8 ; 12,2$ e 15,6 t ha-1 em base seca), e o segundo pelos tempos de incorporação ao solo (0, 10, 20 e 30 dias antes do plantio do coentro). As características avaliadas foram altura de plantas, número de hastes por planta, rendimento de massa verde e massa seca da parte aérea. O melhor desempenho produtivo do coentro foi observado nas quantidades 12,2 (primavera) e 8,8 (outono-inverno) t ha-1 de C. procera adicionada ao solo, com um tempo ideal de incorporação de 13 (primavera) e 23 (outono-inverno) dias antes da semeadura da cultura e com maiores acúmulos de massas verde e seca da parte aérea sendo obtidos no outono-inverno.
\end{abstract}

Termos para indexação: Coriandrum sativum L.; cultivo orgânico; flor-de-seda.

\section{INTRODUCTION}

The cultivation of coriander (Coriandrum sativum L.), a vegetable crop widely consumed and of great socioeconomic importance, has increased exponentially in the Brazilian territory, mainly in the North and Northeast regions of Brazil. Coriander has a short cycle (average of 30 to 40 days), which guarantees a quick return of the invested capital, increasing the income of families in addition to making feasible the use of family labor. Thus, coriander is a species of remarkable social reach (Lira et al., 2015; Pereira et al., 2013).
Most sowing is done in home gardens, which is performed by family farmers using manure (cattle, goats and/ or sheep) as a source of organic fertilizer. Thus, the dependence on these inputs makes the producer vulnerable to scarcity, as the farmer may not always have this resource on the property, which increases production costs (Linhares et al., 2012a).

The restitution of nutrients to the soil is an important practice to obtain good productivities in agriculture. In this aspect, green fertilization stands out as a viable and low-cost alternative (Oliveira et al., 2012). The most-used species 
for green manure have been legumes. However, in recent years, interest has grown in the use of spontaneous plants in this system due to the potential increase in organic matter and the improvement of the physical, microbiological and nutritional qualities of the soil; through proper management, such additions are being used efficiently in the cultivation of vegetable crops (Favero et al., 2000; Góes et al., 2014; Souza et al., 2016).

Working with spontaneous species of the Caatinga hairy woodrose (Merremia aegyptia L.), oneleaf senna (Senna uniflora Mill.) and rooster tree (Calotropis procera (Ait) R. Br.) for green manuring in the Northeast region of Brazil, Batista et al. (2013) obtained an increase in the productivity of these species with increasing doses of green manures incorporated into the soil. This effect stems from the proportionally higher contribution of soil organic matter to the cation exchange capacity and from the nutrient availability flow from cycling processes by microbial biomass and rapid mineralization of the incorporated material. The use of these species in green manuring increased the production of crops such as lettuce and arugula (Linhares et al., 2008; Linhares et al., 2009a, 2009b; Souza et al., 2016, 2017), whose cultivation cycles are similar to coriander.

Evaluating quantities and times of $M$. aegyptia decomposition in coriander culture, Linhares et al. (2012b) obtained a yield of $7.06 \mathrm{t} \mathrm{ha}^{-1}$ with the $15.6 \mathrm{t} \mathrm{ha}^{-1}$ dose of the green manure added 30 days before sowing, which contributed to the good performance of the crop. Souza et al. (2016) observed maximum production of arugula when they incorporated $15.6 \mathrm{t} \mathrm{ha}^{-1}$ of $C$. procera 20 days before planting, in autumn, in Serra Talhada, Pernambuco
State, Brazil. Under the same soil and climatic conditions, Silva et al. (2017) found that the amount of $15.6 \mathrm{t} \mathrm{ha}^{-1}$ of C. procera associated with the 22-day incorporation time was responsible for improved agronomic performance of the radish. C. procera stands out for its adaptation, biomass production capacity throughout the year, ease of management and availability in the Brazilian semi-arid region (Almeida et al., 2015).

Therefore, the objective of this study was to evaluate the agronomic performance of coriander as a function of the added biomass of $C$. procera, incorporation times of green manure and the growing seasons (spring and autumn-winter) under the environmental conditions of Serra Talhada, Pernambuco.

\section{MATERIAL AND METHODS}

Two field experiments were conducted in two growing seasons: spring (October to December 2011) and autumn-winter (May to July 2012), at the Universidade Federal Rural de Pernambuco (UFRPE), Unidade Acadêmica de Serra Talhada (UAST), located at 7²5’'15” south latitude and $38^{\circ} 17^{\prime} 41^{\prime \prime}$ west longitude, at $461 \mathrm{~m}$ altitude, in the microregion of Sertão do Pajeú, north of Pernambuco. The local climate, by Köppen classification, is Bhw, which is described as semi-arid, hot and dry, with summer rains and annual thermal averages of $24.7^{\circ} \mathrm{C}$ and average annual precipitation of $642.1 \mathrm{~mm}$ (Medeiros et al., 2005; SUDENE, 1990). The average meteorological data from the period of the experiments are shown in Figure 1.

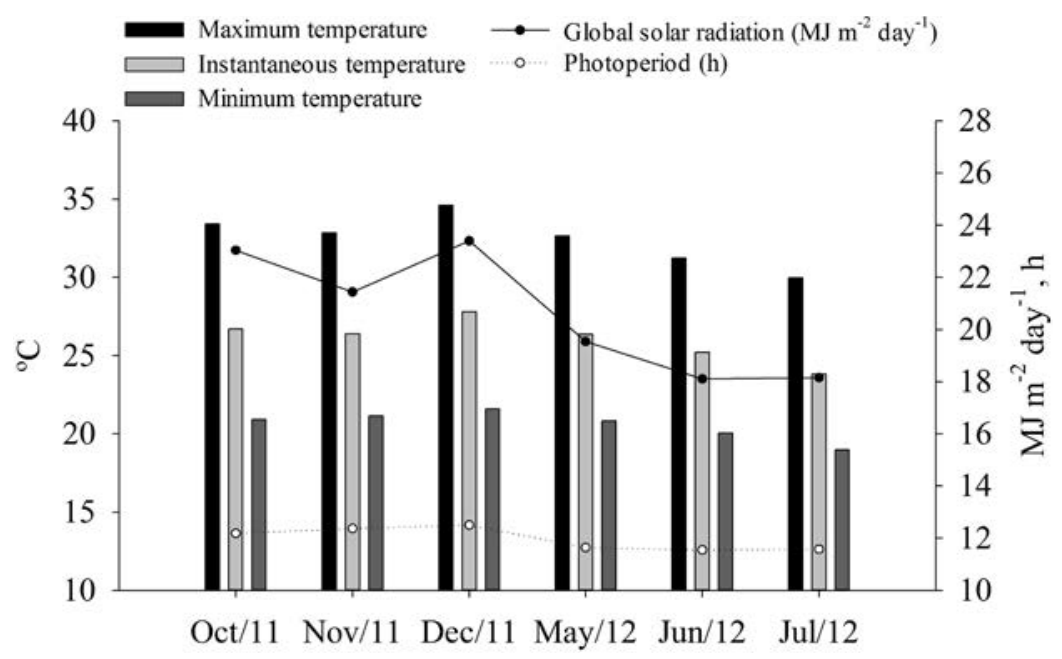

Figure 1: Monthly mean values of instantaneous temperatures $\left({ }^{\circ} \mathrm{C}\right)$, maximum and minimum, global solar

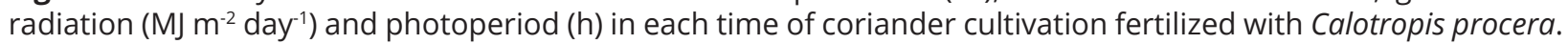


The soil of the experimental area is classified as a Cambissolo Háplico Ta Eutrófico (Santos et al., 2013), sandy loam texture ( sand $=783.6 \mathrm{~g} \mathrm{~kg}^{-1}$, silt $=100.4 \mathrm{~g} \mathrm{~kg}^{-1}$, and clay $=116.0 \mathrm{~g} \mathrm{~kg}^{-1}$ ), whose chemical characteristics (Silva, 2009), at a depth of 0-0.20 m before the start of the experiments, in spring, were $\mathrm{pH}$ in $\mathrm{H}_{2} \mathrm{O}(1: 2.5)=6.6$, organic matter $(\mathrm{OM})=8.4 \mathrm{~g} \mathrm{~kg}^{-1}, \mathrm{P}=15.0 \mathrm{mg} \mathrm{dm}^{-3}, \mathrm{~K}^{+}=$ $0.7 \mathrm{cmol}_{\mathrm{c}} \mathrm{dm}^{-3}, \mathrm{Ca}^{2+}=3.4 \mathrm{cmol}_{\mathrm{c}} \mathrm{dm}^{-3}, \mathrm{Mg}^{2+}=2.0 \mathrm{cmol}_{\mathrm{c}}$ $\mathrm{dm}^{-3}$, and $\mathrm{Al}^{3+}=0.0 \mathrm{cmol} \mathrm{dm}^{-3}$, and in autumn-winter, were $\mathrm{pH}$ in $\mathrm{H}_{2} \mathrm{O}(1: 2.5)=6.5, \mathrm{OM}=12.7 \mathrm{~g} \mathrm{~kg}^{-1}, \mathrm{P}=20.0 \mathrm{mg}$ $\mathrm{dm}^{-3}, \mathrm{~K}^{+}=0.4 \mathrm{cmol}_{\mathrm{c}} \mathrm{dm}^{-3}, \mathrm{Ca}^{2+}=3.4 \mathrm{cmol}_{\mathrm{c}} \mathrm{dm}^{-3}, \mathrm{Mg}^{2+}=$ $2.0 \mathrm{cmol}_{\mathrm{c}} \mathrm{dm}^{-3}$, and $\mathrm{Al}^{3+}=0.0 \mathrm{cmol}_{c} \mathrm{dm}^{-3}$.

The experimental design was in randomized blocks, with three replications. The treatments were arranged in a $4 \times 4$ factorial scheme, with the first factor consisting of four biomass amounts of $C$. procera (5.4, 8.8, 12.2 and $15.6 \mathrm{t} \mathrm{ha}^{-1}$ on a dry basis), and the second factor, by four times of incorporation into the soil of this fertilizer $(0,10$, 20 and 30 days before sowing of the coriander).

Each experimental unit had a total area of $1.44 \mathrm{~m}^{2}$, with a harvest plot of $0.80 \mathrm{~m}^{2}$. Six rows or planting lines were arranged transversely in each plot, spaced $0.20 \mathrm{~m}$ apart, and within row spacing between plants of $0.05 \mathrm{~m}$. The coriander cultivar planted was Verdão, indicated for cultivation in the Northeast region. Soil preparation in each experiment consisted of the raising of the beds using hoes.

The $C$. procera was collected in areas near the experimental area, crushed in a conventional forage machine, with uniform particles of approximately two to three centimeters being obtained. Drying was performed in the shade until the plant particles reached the point of hay ( $10 \%$ of humidity). The material was analyzed and the dry matter exhibited the following nutrient content: $\mathrm{N}=17.4$ $\mathrm{g} \mathrm{kg}^{-1}, \mathrm{P}=4.4 \mathrm{~g} \mathrm{~kg}^{-1}, \mathrm{~K}=23.5 \mathrm{~g} \mathrm{~kg}^{-1}, \mathrm{Ca}=14.3 \mathrm{~g} \mathrm{~kg}^{-1}, \mathrm{Mg}$ $=23.0 \mathrm{~g} \mathrm{~kg}^{-1}, \mathrm{Fe}=463.0 \mathrm{mg} \mathrm{kg}^{-1}, \mathrm{Zn}=40.0 \mathrm{mg} \mathrm{kg}^{-1}, \mathrm{Cu}$ $=29.0 \mathrm{mg} \mathrm{kg}^{-1}, \mathrm{Mn}=90.0 \mathrm{mg} \mathrm{kg}^{-1}, \mathrm{~B}=71.0 \mathrm{mg} \mathrm{kg}^{-1}, \mathrm{Na}$ $=1,640.0 \mathrm{mg} \mathrm{kg}^{-1}, \mathrm{OM}=764.0 \mathrm{mg} \mathrm{kg}^{-1}$ and $\mathrm{C} / \mathrm{N}=25 / 1$.

The fertilizer was incorporated in the $0-0.20 \mathrm{~m}$ layer of the soil in the experimental plots, according to the treatments. Daily irrigations were carried out in two shifts for the purpose of favoring the microbial activity of the soil in the organic matter mineralization process.

The planting of the coriander in the first growing season (spring) was performed on November 12, 2011, whereas in autumn-winter, this was done on June 1, 2012. A direct seeding at two centimeters deep was performed, with three seeds being sown per hole. Ten days after emergence, thinning occurred, with one plant being left per hole. Irrigation was performed with a microsprinkler system, with two daily waterings - one in the morning and another in the afternoon - supplying a water sheet, on average, of $8 \mathrm{~mm}^{\text {day }}{ }^{-1}$, pumped from a weir. Weed control was performed whenever necessary.

In the spring, the coriander harvest was conducted at 38 days after sowing (DAS), whereas in autumn-winter, it was at 40 DAS. At harvest, the following characteristics were evaluated: the height of the plants, expressed in $\mathrm{cm}$, obtained by measuring, with a ruler, a sample of twenty plants from the ground level to the end of the highest leaf; number of stems per plant, determined by direct counting of the number of stems in a sample of twenty plants; yield of green mass obtained from the fresh mass of the shoot of all the plants present in the harvest area of the plot and expressed in $\mathrm{tha}^{-1}$; and the dry mass of the shoot, estimated from the weight of the dry mass of the plants of the harvest area, after oven drying with forced air circulation, at a temperature set at $65^{\circ} \mathrm{C}$, until a constant mass, expressed in $\mathrm{tha}^{-1}$, was reached.

For each growing season, univariate analyses of variance were performed for the characteristics evaluated through the Sisvar application (Ferreira, 2011). A joint analysis was performed for the characteristic(s) showing homogeneity of variances between the growing seasons (Pimentel-Gomes, 2009). An adjustment procedure for the response curves was done between the evaluated characteristics and the quantitative factors through the program SigmaPlot 12.0 (Systat Software, 2011). Tukey's test $(p<0.05)$ was used to compare the means of the qualitative treatment.

\section{RESULTS AND DISCUSSION}

\section{Joint analysis of variance}

According to the results of the joint analysis of the variables evaluated as a function of growing seasons, the biomass of $C$. procera and the times of incorporation of each to the soil showed a double interaction between the growing seasons and the amounts of $C$. procera, as well as between the seasons and the incorporation times of the green manure for the variables of plant height and shoot dry mass (Table 1 ). Shoot dry mass was significantly influenced by the interaction of the amounts of $C$. procera with their incorporation times. For the number of stems per plant and yield of green mass, an interaction occurred among the three factors.

\section{Plant height $(\mathrm{cm})$}

In autumn-winter, plant height reduced linearly with increasing amounts of $C$. procera (Figure 2A). For each ton added to the soil, decreases of $0.22 \mathrm{~cm}$ occurred in this variable relative to green fertilization 
with $5.4 \mathrm{t} \mathrm{ha}^{-1}(17.28 \mathrm{~cm})$. No regression curve was fitted for the spring cultivation (mean of $9.35 \mathrm{~cm}$ ). On the other hand, an evaluation of the growing seasons within each amount of $C$. procera biomass showed that greater heights of coriander plants were obtained when the crop was planted in autumn-winter (Table 2).

Increasing values were observed for the plant height in the autumn-winter when the green manure was incorporated 23 days before sowing, in which the coriander reached an estimated maximum height of $18.38 \mathrm{~cm}$ and then declined (Figure 2B). For the spring, adjustment of the regression equation (mean of $9.35 \mathrm{~cm}$ ) was not possible. Evaluation of the growing seasons within each incorporation time revealed that the height of plants in autumn-winter was higher that than in the spring season, regardless of the period of permanence in the soil of the green manure (Table 3).

\section{Shoot dry mass (t ha-1)}

The shoot dry mass of the coriander reached a maximum value of $0.55 \mathrm{tha}^{-1}$ in the spring season, associated with fertilization with 12.78 tha $^{-1}$ of $C$. procera (Figure $3 \mathrm{~A}$ ), whereas no adjustments were made to the regression curve when the plants were cultivated in autumn-winter, when the average dry mass accumulation was $0.60 \mathrm{t} \mathrm{ha}^{-1}$. Coriander dry mass yield in the spring was statistically higher than that of autumn-winter at the doses of 5.4 and $8.8 \mathrm{t} \mathrm{ha}^{-1}$ of C. procera, and statistically similar in the dose of $12.2 \mathrm{t} \mathrm{ha}^{-1}$ (Table 4). In the dose of $15.6 \mathrm{t} \mathrm{ha}^{-1}$, the dry mass yield in the autumn-winter cultivation was superior to the spring.

Table 1: Summary of the analysis of variance analysis for plant height (PH), number of stems per plant (NSP), green mass yield (GMY) and shoot dry mass (SDM) of coriander plants fertilized with Calotropis procera in two growing seasons.

\begin{tabular}{|c|c|c|c|c|c|}
\hline Sources of variation & $\mathrm{df}$ & $\mathrm{PH}$ & NSP & GMY & SDM \\
\hline Blocks (Seasons) & 4 & $2.13^{\text {ns }}$ & $0.47^{\text {ns }}$ & $3.51 *$ & $0.91^{\mathrm{ns}}$ \\
\hline Seasons & 1 & $241.78^{* *}$ & $459.07 * *$ & $12.77 * *$ & $75.91 * *$ \\
\hline Amounts & 3 & $1.64^{\mathrm{ns}}$ & $0.82^{\text {ns }}$ & $3.63^{*}$ & $5.87 * *$ \\
\hline Times & 3 & $16.80 * *$ & $13.81 * *$ & $23.55 * *$ & $21.47 * \star$ \\
\hline Seasons $\times$ Amounts & 3 & $3.36 *$ & $6.60 * *$ & $7.05^{* *}$ & $11.38 * *$ \\
\hline Seasons $x$ Times & 3 & $8.24 * \star$ & $1.45^{\mathrm{ns}}$ & $8.26 * *$ & $14.22 * *$ \\
\hline Amounts $x$ Times & 9 & $0.78^{\text {ns }}$ & $1.42^{\text {ns }}$ & $2.74 * *$ & $3.95 * *$ \\
\hline Seasons $\times$ Amounts $\times$ Times & 9 & $1.32^{\mathrm{ns}}$ & $2.09 *$ & $2.36^{*}$ & $2.02^{\mathrm{ns}}$ \\
\hline C.V. (\%) & & 14.51 & 11.97 & 20.06 & 14.11 \\
\hline Overall Mean & & 12.14 & 6.08 & 2.81 & 0.53 \\
\hline
\end{tabular}

ns: Not significant. ** and *: significant at the $1 \%$ and $5 \%$ probability level, by the $\mathrm{F}$ test, respectively.
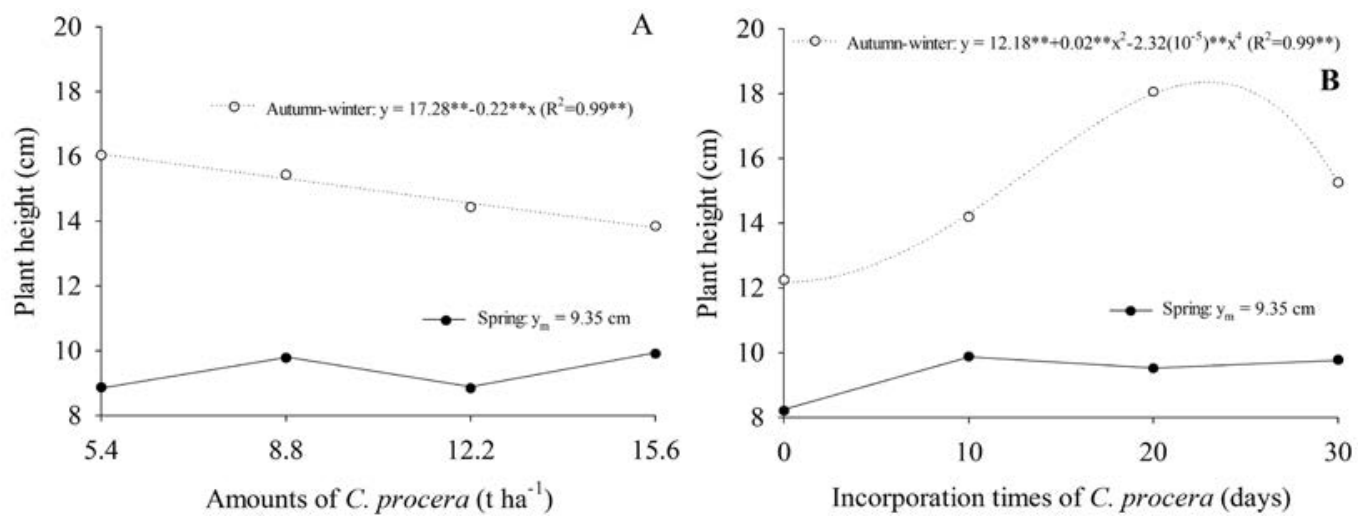

Figure 2: Plant height of coriander as a function of interactions: amounts of Calotropis procera and growing seasons $(A)$ and times of incorporation to the soil of the green manure and growing seasons (B). 
Table 2: Mean values of coriander plant height from the interaction between growing seasons and biomass of Calotropis procera.

\begin{tabular}{ccccc}
\hline \multirow{2}{*}{ Growing seasons } & \multicolumn{4}{c}{ Amounts of C. procera $\left(\mathrm{t} \mathrm{ha}^{-1}\right)$} \\
\cline { 2 - 5 } & 5.4 & 8.8 & 12.2 & 15.6 \\
\hline Spring & & \multicolumn{4}{c}{ Plant height (cm) } \\
Autumn-winter & $8.87 \mathrm{~b}^{1}$ & $9.78 \mathrm{~b}$ & $8.84 \mathrm{~b}$ & $9.91 \mathrm{~b}$ \\
\hline
\end{tabular}

${ }^{1}$ Means followed by the same letter in the column do not differ by the Tukey test at the $5 \%$ probability level.

Table 3: Mean values of coriander plant height from the interaction between growing seasons and incorporation times into the soil of Calotropis procera.

\begin{tabular}{ccccc}
\hline \multirow{2}{*}{ Growing seasons } & \multicolumn{4}{c}{ Incorporation times of C. procera (days) } \\
\cline { 2 - 5 } & 0 & 10 & 20 & 30 \\
\hline Spring & \multicolumn{4}{c}{ Plant height (cm) } \\
Autumn-winter & $8.21 \mathrm{~b}^{1}$ & $9.88 \mathrm{~b}$ & $9.52 \mathrm{~b}$ & $9.78 \mathrm{~b}$ \\
\hline
\end{tabular}

${ }^{1}$ Means followed by the same letter in the column do not differ by the Tukey test at the $5 \%$ probability level.
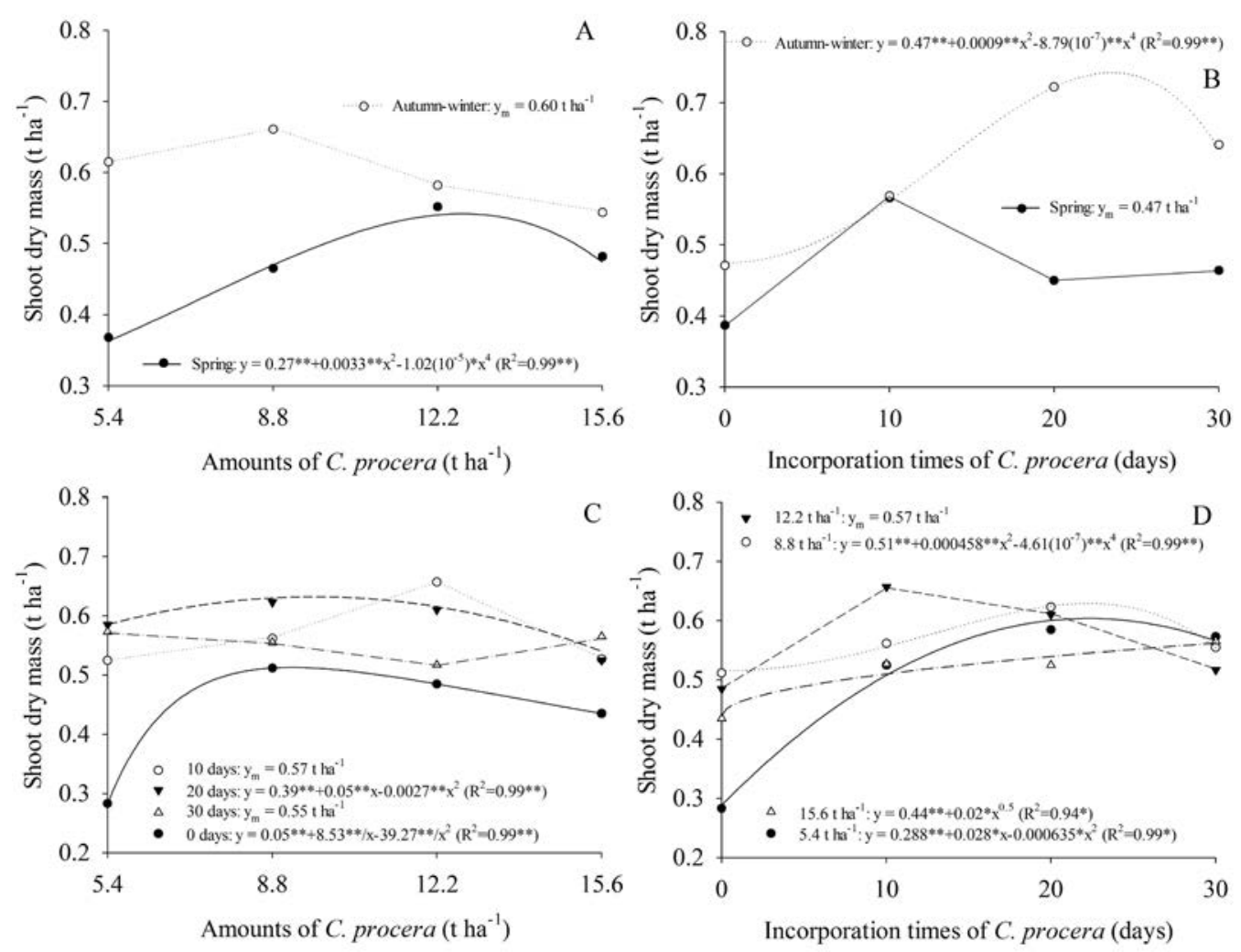

Figure 3: Shoot dry mass of coriander as a function of interactions: amounts of Calotropis procera and growing seasons (A), times of incorporation to the soil of the green manure and growing seasons (B), amounts of $C$. procera and times of incorporation (C), and the inverse (D). 
Table 4: Mean values of dry mass of coriander shoots from the interaction between growing seasons and biomass of Calotropis procera.

\begin{tabular}{ccccc}
\hline \multirow{2}{*}{ Growing seasons } & \multicolumn{4}{c}{ Amounts of C. procera $\left(\mathrm{t} \mathrm{ha}^{-1}\right)$} \\
\cline { 2 - 5 } & 5.4 & 8.8 & 12.2 & 15.6 \\
\hline Spring & $0.61 \mathrm{a}^{1}$ & $0.66 \mathrm{a}$ & $0.55 \mathrm{a}$ & $0.48 \mathrm{~b}$ \\
Autumn-winter & $0.37 \mathrm{~b}$ & $0.46 \mathrm{~b}$ & $0.58 \mathrm{a}$ & $0.54 \mathrm{a}$ \\
\hline
\end{tabular}

${ }^{1}$ Means followed by the same letter in the column do not differ by the Tukey test at the $5 \%$ probability level.

The estimated incorporation time in 23.56 days provided the highest yield of coriander dry mass in autumnwinter $\left(0.74 \mathrm{tha}^{-1}\right)$ (Figure 3B). No regression curve was fitted for the spring (mean $0.47 \mathrm{t} \mathrm{ha}^{-1}$ ). An evaluation of the growing seasons within each incorporation time revealed that the autumn-winter cultivation yielded mean values of dry mass higher than in the spring, except at 10 days (Table 5).

The estimated dose of $9.4 \mathrm{t} \mathrm{ha}^{-1}$ of $C$. procera with an incorporation time of 20 days provided the highest dry mass result of coriander shoot $\left(0.63 \mathrm{t} \mathrm{ha}^{-1}\right)$ (Figure 3C). No adjustment of the regression curves was required for the times of $10\left(0.57 \mathrm{t} \mathrm{ha}^{-1}\right)$ and 30 days $\left(0.55 \mathrm{t} \mathrm{ha}^{-1}\right)$, with a greater average value $\left(0.66 \mathrm{t} \mathrm{ha}^{-1}\right)$ being verified for incorporation time of 10 days associated with the dose of $12.2 \mathrm{t} \mathrm{ha}^{-1}$ of $C$. procera. The dry mass yield also increased in a biquadratic manner with the incorporation times of the green manure to the soil, where the amount of $8.8 \mathrm{t} \mathrm{ha}^{-1}$ of C. procera, associated with the estimated time of 22.29 days, reached a maximum value of $0.63 \mathrm{tha}^{-1}$, then decreased until the last incorporation time (Figure 3D).

\section{Number of stems per plant}

Regarding the number of stems per coriander plant as a function of the interaction of $C$. procera amounts and incorporation times, no adjustments were required for the regression curves for the spring cultivation, with the highest average value observed for the time of 20 days (8.26 stems per plant) (Figure 4A). In general, the coriander produced in the autumn-winter showed a reduction in the number of stems per plant with the increase in green manure, for which the amount of $5.4 \mathrm{tha}^{-1}$ of $C$. procera combined with the time of 20 days obtained the maximum average of 5.81 stems per plant (Figure 4B).

An evaluation of the incorporation times as a function of the $C$. procera amounts, in the coriander spring crop, an optimum time association of 19.53 days with $12.2 \mathrm{t} \mathrm{ha}^{-1}$ of green manure was highlighted, with a maximum number of 8.00 stems per plant being obtained (Figure 4C). No adjustment of the regression curves was required for the treatments for the amounts of 5.4, 8.8 and $15.6 \mathrm{t} \mathrm{ha}^{-1}$. In autumn-winter (Figure 4D), the highest number of stems per coriander plant ( 5.70 stems) was reached with the amounts of 5.4 and $8.8 \mathrm{t} \mathrm{ha}^{-1}$ of $C$. procera with an incorporation time of 23 days.

\section{Green mass yield (t ha-1)}

The green mass yield of coriander reached a maximum value of $4.16 \mathrm{tha}^{-1}$ in the spring crop, associated with the amount of $12.2 \mathrm{t} \mathrm{ha}^{-1}$ of $C$. procera fertilized 10 days before the crop was sown (Figure 5A). In autumnwinter, a maximum yield $\left(4.92 \mathrm{t} \mathrm{ha}^{-1}\right)$ was observed in the amount of $8.8 \mathrm{t} \mathrm{ha}^{-1}$ of $C$. procera with an incorporation time of 20 days (Figure 5B). The estimated incorporation time at 13 days, along with the $12.2 \mathrm{t} \mathrm{ha}^{-1}$ dose of $C$. procera, provided the highest yield of coriander green mass in spring ( $4.10 \mathrm{t} \mathrm{ha}^{-1}$ ) (Figure 5C). In the second growing season (autumn-winter), the association of the optimized time of 23 days with the $8.8 \mathrm{t} \mathrm{ha}^{-1}$ dose of green manure (Figure 5D) was highlighted, with a maximum yield of $5.11 \mathrm{t} \mathrm{ha}^{-1}$ being obtained, which was superior to that obtained in the spring.

\section{Effects of $C$. procera amounts}

The green and dry mass yields of coriander shoots fertilized with C. procera increased with the increasing amounts of green manure, reaching maximum values of 12.2 (spring) and $8.8 \mathrm{t} \mathrm{ha}^{-1}$ (autumn-winter), then decreasing up to the last amount of biomass evaluated. Most likely, these doses promoted a better balance between the nutritional demand of the crop and the nutrient supply by the soil, since green fertilization with C. procera provides macro- and micronutrients to the soil, besides favoring the development of actinomycetes, fungi and bacteria beneficial to plant growth (Batista et al., 2013, 2016). 
Table 5: Mean values of dry mass of coriander shoots from the interaction between growing seasons and incorporation times to the soil of Calotropis procera.

\begin{tabular}{ccccc}
\hline \multirow{2}{*}{ Growing seasons } & \multicolumn{4}{c}{ Incorporation times of C. procera (days) } \\
\cline { 2 - 5 } & 0 & 10 & 20 & 30 \\
\hline Spring & & Shoot dry mass (t ha ${ }^{-1}$ ) \\
Autumn-winter & $0.39 \mathrm{~b}^{1}$ & $0.57 \mathrm{a}$ & $0.45 \mathrm{~b}$ & $0.46 \mathrm{~b}$ \\
\hline
\end{tabular}

${ }^{1}$ Means followed by the same letter in the column do not differ by the Tukey test at the 5\% probability level.
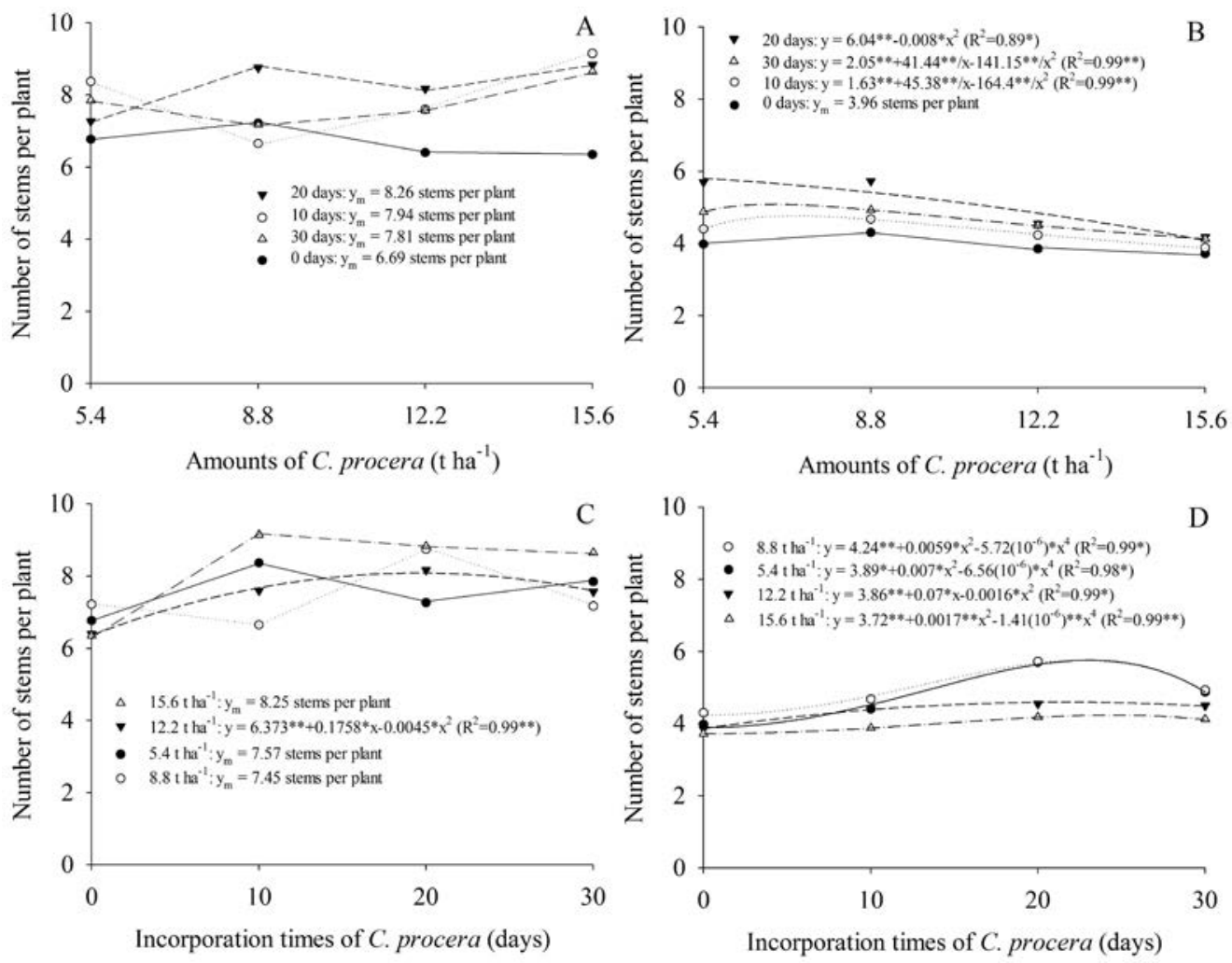

Figure 4: Number of stems per coriander plant as a function of the interaction of the amounts of Calotropis procera biomass and the time of incorporation into the soil of the green manure (A. spring, B. autumn-winter) and the inverse (C. spring, D. autumn-winter) in each growing season.

However, the higher amounts of $C$. procera biomass may have had a negative effect on seedling emergence, with a reduction in productivity, as the coriander is very sensitive to the possible mechanical resistance caused by fragments of green manure deposited on the soil surface. To avoid such a problem, a deeper incorporation of $C$. procera biomass is critical, especially in autumn-winter.

Different results were observed by Linhares et al. (2014), who did not report problems with emergence of the coriander fertilized with the highest amount of $C$. procera $\left(15.6 \mathrm{t} \mathrm{ha}^{-1}\right)$ in the spring in Mossoró-RN, where plants reached $18.20 \mathrm{~cm}$ in height, had 9.00 stems per plant, presented $4.40 \mathrm{t} \mathrm{ha}^{-1}$ of fresh yield and produced $0.85 \mathrm{t} \mathrm{ha}^{-1}$ of accumulated dry mass. Most likely, the better management in the incorporation of $C$. procera in this work avoided problems with the emergence of coriander plants. Under these same environmental and soil conditions, Linhares et al. (2012b) obtained 

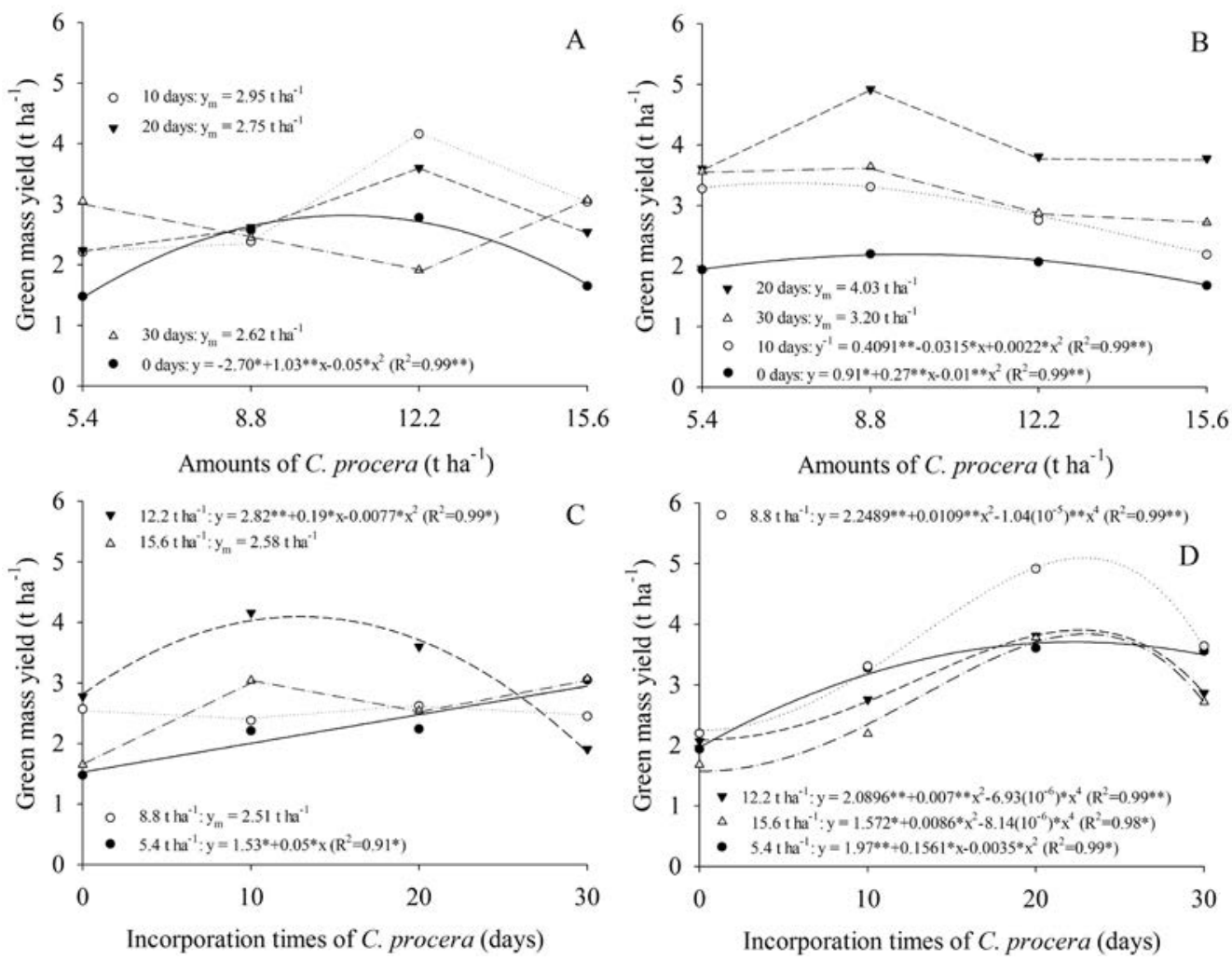

Figure 5: The green mass yield of coriander as a function of the interaction of the biomass amounts of Calotropis procera and the times of incorporation into the soil of the green manure (A. spring, B. autumn-winter) and the inverse (C. spring, D. autumn-winter) in each growing season.

maximum yields of green $\left(7.01 \mathrm{t} \mathrm{ha}^{-1}\right)$ and dry $(0.72 \mathrm{t}$ $\mathrm{ha}^{-1}$ ) mass of coriander with $15.6 \mathrm{t} \mathrm{ha}^{-1}$ of $M$. aegyptia, justifying the superiority of this species over C. procera in the functioning of the higher content of nutrients, mainly $\mathrm{N}\left(25.6 \mathrm{~g} \mathrm{~kg}^{-1}\right)$.

In conventional production systems, the green mass yield of coriander showed increasing agronomic responses, with $\mathrm{N}$ doses of 94 (Angeli et al., 2016) and $213 \mathrm{~kg} \mathrm{ha}^{-1}$ (Oliveira et al., 2003) providing productivity results of 20.30 (cv. Vedete) and $37.66 \mathrm{t}$ ha $^{-1}$ (cv. Verdão), respectively. In the study by Oliveira et al. (2003), organic ( $5 \mathrm{~kg} \mathrm{~m}^{-2}$ of bovine manure) and chemical fertilizations (doses of $\mathrm{N}$ evaluated in the form of ammonium sulfate) were used, whereas Angeli et al. (2016) used only mineral sources of $\mathrm{N}$ : monoammonium phosphate (MAP) and urea. In addition to the effect of these high doses of $\mathrm{N}$, the high yields of coriander green mass can be explained by the occurrence of average temperatures below $25{ }^{\circ} \mathrm{C}$ in both experiments, which increased the cycle of coriander vegetative development (46 to 50 days).

\section{Effects of soil incorporation times of $C$. procera}

In the spring and autumn-winter, the productive behavior of coriander also increased with the times of incorporation to the soil of $C$. procera, until approximately 13 and 23 days, respectively, with a subsequent decrease. Similar results were observed by Souza et al. (2017), where the ideal time for the incorporation of $C$. procera was 10 (spring) and 20 (autumn-winter) days before lettuce transplanting in Serra Talhada-PE. On the other hand, Linhares et al. (2014) recommend incorporating C. procera 30 days before planting coriander in the spring in Mossoró$\mathrm{RN}$. These results show that environmental conditions directly influence green manuring and crop performance.

The study of the time of incorporation into the soil of the green manure allows identification of the moment of synchrony between the mineralization of the vegetal residue and the period of maximum nutritional requirement of the coriander (Myers et al., 1994); that is, organic fertilization at the ideal moment for each condition allows the vegetal material to make the nutrients present in its chemical 
composition available in the soil solution, thus favoring the absorption and accumulation of biomass by the plants.

According to Grangeiro et al. (2011), the greatest nutrient demands by coriander occur in the period between 30 and 35 days after sowing, thus providing the highest availability of nutrients at 45 (spring) and 55 (autumnwinter) days after incorporation of the green fertilizer.

Torres et al. (2005) verified that the greater mineralization of $\mathrm{N}$ in cultures using green manures occurred in the first 42 days after being desiccated, relating this mineralization to the low $\mathrm{C} / \mathrm{N}$ ratio of the vegetable material (20-25/1). This proportion is similar to that observed in the chemical composition of the C. procera (25/1). Thus, the recommended time changed between the growing seasons, perhaps because the variation in temperature and solar radiation promoted changes in the speed of the reactions between the microbiota and the soil organic matter, with higher microbial activity being probable the in spring (Lourente et al., 2011).

\section{Effects of growing seasons}

In general, in the coriander autumn-winter planting, the plant height, shoot dry mass and green mass yield were higher than the values obtained in the spring crop. These results are due to milder average temperatures (close to $25^{\circ} \mathrm{C}$ ), lower solar radiation and a photoperiod of less than $12 \mathrm{~h}$ in autumn-winter (Figure 1), which probably favored the vegetative growth of the crop. On the other hand, in the spring, the average maximum temperatures were above $34^{\circ} \mathrm{C}$, and the days had more than $12 \mathrm{~h}$ of light (Figure 1), possibly promoting a negative effect on coriander growth.

These data corroborate the findings of Lima et al. (2007), who, while working with the same cultivar of coriander cv. Verdão in the soil-climatic conditions of Mossoró-RN, observed a higher agronomic yield of this vegetable crop when cultivated in the winter $\left(5.00 \mathrm{t} \mathrm{ha}^{-1}\right)$ compared to in spring $\left(3.39 \mathrm{t} \mathrm{ha}^{-1}\right)$ and justified such results with the meteorological information of the planting periods, which was similar to that of the present research. Similar results were also observed in arugula and radish fertilized with C. procera in two growing seasons in the municipality of Serra Talhada-PE (Silva et al., 2017; Souza et al., 2016).

The coriander plant presented a higher number of stems in the spring (Figure 4), associated with a lower yield of green mass (Figure 5), indicating that a high percentage of stems relative to the formation of leaves confers a lower quality on the coriander. The planting of leafy vegetable crops in periods characterized by maximum temperatures above $30^{\circ} \mathrm{C}$ can promote a short vegetative cycle, reduction in the leaf numbers, and early flowering, with consequent depreciation of quality (Feltrim et al., 2005). Because the harvesting point of the coriander consists of the period immediately prior to the tasseling, these characteristics associated with maximum temperatures can be confirmed by the differences observed between the cultural cycles in the spring (38 DAS) and autumn-winter (40 DAS).

Therefore, the cultivation of coriander cv. Verdão manured with $C$. procera is recommended for both growing seasons. However, in the autumn-winter planting with $8.8 \mathrm{t}$ $\mathrm{ha}^{-1}$ of the green manure added to the soil at 23 days before planting the crop, an $18 \%$ increase can be obtained in the yield of green mass relative to the cultivation in the spring.

\section{CONCLUSIONS}

The cultivation in autumn-winter promoted greater accumulations of green and dry mass in the coriander shoot fertilized with C. procera. The best productive performance of coriander was observed with the addition of $C$. procera to the soil in the amounts of $12.2 \mathrm{t} \mathrm{ha}^{-1}$ (spring) and $8.8 \mathrm{t}$ ha $^{-1}$ (autumn-winter). The ideal incorporation time of the green manure consisted of 13 (spring) and 23 (autumnwinter) days before planting of the coriander.

\section{REFERENCES}

ALMEIDA, A. E. S. et al. Eficiência agronômica do consórcio alface-rúcula fertilizado com Flor-de-Seda. Revista Caatinga, 28(3):79-85, 2015.

ANGELI, K. P. et al. Yield components and water use efficiency in coriander under irrigation and nitrogen fertilization. Revista Brasileira de Engenharia Agrícola e Ambiental, 20(5):415-420, 2016.

BATISTA, M. A. V. et al. Atributos microbiológicos do solo e produtividade de rabanete influenciados pelo uso de espécies espontâneas. Horticultura Brasileira, 31(4):587-594, 2013.

BATISTA, M. A. V. et al. Atributos de solo-planta e de produção de beterraba influenciados pela adubação com espécies da Caatinga. Horticultura Brasileira, 34(1):31-38, 2016.

FAVERO, C. et al. Crescimento e acúmulo de nutrientes por plantas espontâneas e por leguminosas utilizadas para adubação verde. Revista Brasileira de Ciência do Solo, 24(1):171-177, 2000.

FELTRIM, A. L. et al. Produção de alface americana em solo e em hidroponia, no inverno e verão, em Jaboticabal, SP. Revista Brasileira de Engenharia Agrícola e Ambiental, 9(4):505-509, 2005. 
FERREIRA, D. F. Sisvar: A computer statistical analysis system. Ciência e Agrotecnologia, 35(6):1039-1042, 2011.

GÓES, S. B. et al. Change in the $\mathrm{pH}$ and macronutrients in soil fertilized with hairy woodrose in different amounts and times of incorporation. Revista Caatinga, 27(3):110, 2014.

GRANGEIRO, L. C. et al. Crescimento e acúmulo de nutrientes em coentro e rúcula. Revista Agrária, 6(1):11-16, 2011.

LIMA, J. S. S. et al. Desempenho agroeconômico de coentro em função de espaçamentos e em dois cultivos. Revista Ciência Agronômica, 38(4):407-413, 2007.

LINHARES, P. C. F. et al. Roostertree (Calotropis procera) under different amounts and periods of incorporation on yield of coriander. Revista Verde de Agroecologia e Desenvolvimento Sustentável, 9(3):7-12, 2014.

LINHARES, P. C. F. et al. Rendimento de coentro (Coriandrum sativum L.) em sistema de adubação verde com a planta jitirana (Merremia aegyptia L.). Revista Brasileira de Plantas Medicinais, 14:143-148, $2012 a$.

LINHARES, P. C. F. et al. Quantidades e tempos de decomposição da jitirana no desempenho agronômico do coentro. Ciencia Rural, 42(2):243-248, 2012b.

LINHARES, P. C. F. et al. Velocidade de decomposição da flor-deseda no desempenho agronômico da rúcula cv. Cultivada. Revista Verde de Agroecologia e Desenvolvimento Sustentável, 4(2):46-50, 2009a.

LINHARES, P. C. F. et al. Influência da jitirana em cobertura como adubação verde sobre o desempenho agronômico da alface. Revista Caatinga, 22(4):65-69, 2009b.

LINHARES, P. C. F. et al. Adição de jitirana ao solo no desempenho de rúcula cv. Folha Larga. Revista Caatinga, 21(5):89-94, 2008.

LIRA, R. M. et al. Cultivo de coentro em diferentes níveis de salinidade e umidade do solo. Revista Geama Environmental Sciences, 3(1):51-61, 2015.

LOURENTE, E. R. P. et al. Atributos microbiológicos, químicos e físicos de solo sob diferentes sistemas de manejo e condições de Cerrado. Pesquisa Agropecuária Tropical, 41(1):20-28, 2011.

MEDEIROS, S. S. et al. Estimativa e espacialização das temperaturas do ar mínimas, médias e máximas na Região Nordeste do Brasil. Revista Brasileira de Engenharia Agrícola e Ambiental, 9(2):247-255, 2005.
MYERS, R. J. K. et al. The synchronization of nutrient mineralization and plant nutrient demand. In: WOOMER, P. L.; SWIFT, M. J. (Eds.). The biological management of tropical soil fertility. New York: John Wiley and Sons, 1994. p.81-116.

OLIVEIRA, A. P. et al. Rendimento de coentro cultivado com doses crescentes de N. Horticultura Brasileira, 21(1):8183, 2003.

OLIVEIRA, A. P. et al. Tecnologia alternativa para produção de túberas-semente de inhame e seus reflexos na produtividade. Horticultura Brasileira, 30(3):553-556, 2012.

PEREIRA, M. F. S. et al. Composição nutricional de cultivares de coentro por ocasião do teste de emergência de plântulas. Revista Verde de Agroecologia e Desenvolvimento Sustentável, 7(5):1-5, 2013

PIMENTEL-GOMES, F. Curso de estatística experimental. 15. ed. São Paulo: FEALQ, 2009. 451p.

SANTOS, H. G. et al. Sistema brasileiro de classificação de solos. 3. ed. rev. ampl. Brasília: Embrapa, 2013. 353p.

SILVA, A. F. A. et al. Desempenho agronômico do rabanete adubado com Calotropis procera (Ait.) R. Br. em duas épocas de cultivo. Revista Ciência Agronômica, 48(2):328-336, 2017.

SILVA, F. C. (Ed.). Manual de análises químicas de solos, plantas e fertilizantes. 2. ed. rev. ampl. Brasília: Embrapa Informação Tecnológica, 2009. 627p.

SOUZA, Ê. G. F. et al. Production of lettuce under green manuring with Calotropis procera in two cultivation seasons. Revista Caatinga, 30(2):391-400, 2017.

SOUZA, Ê. G. F. et al. Agronomic response of arugula to green fertilization with rooster tree during two culture times. African Journal of Agricultural Research, 11(48):49314938, 2016.

SUPERINTENDÊNCIA DE DESENVOLVIMENTO DO NORDESTE SUDENE. Dados pluviométricos mensais do Nordeste: Estado de Pernambuco. Recife: Grafset, 1990. 363p. (Séries Pluviométricas, 6).

SYSTAT SOFTWARE. SigmaPlot for Windows Version 12.0. San Jose: Systat Software Inc., 2011.

TORRES, J. L. R. et al. Decomposição e liberação de nitrogênio de resíduos culturais de plantas de cobertura em um solo de cerrado. Revista Brasileira de Ciência do Solo, 29(4):609-618, 2005. 